\title{
Glacial relicts in the Alps: the decline and conservation strategy for Nuphar pumila (Nymphaeaceae)
}

\author{
Sébastien Bétrisey ${ }^{1,2} \cdot$ Nils Arrigo $^{3} \cdot$ Larissa Graf $^{4} \cdot$ Julia Bilat $^{3} \cdot$ Emanuel Gerber $^{1} \cdot$ Gregor Kozlowski $^{1,2}$
}

\begin{abstract}
The Alps played an important role in the biogeography of European plants and acted as a refugium for numerous species during the interglacial cycles. We investigated Nuphar pumila, one of the most emblematic glacial relicts of the Alps, by carrying out exhaustive literature and field surveys to collect relevant data on its distribution and threats. We further evaluated the level of introgression with the closely related $N$. lutea based on microsatellite data from natural populations across the Alps as well as from all ex situ collections and reintroductions in Switzerland. According to our results, more than $60 \%$ of the known $N$. pumila populations went extinct, and the species currently presents 37 natural populations in the investigated area. A large number of populations were affected by eutrophication (69\%) and hybridization with $N$. lutea $(53 \%)$. Prior-ity should be given to the in situ conservation of genetically pure populations, while ex situ cultures should be applied to nearly extinct populations and the genetically pure individuals still present in hybrid populations. $N$. pumila is an excellent representative of the wetland/aquatic glacial relicts that are particularly affected by the combination of climate change and habitat degradation. International integration of research and conservation programs is needed to limit the decline of such rare species in the Alps.
\end{abstract}

Keywords Climate relict $\cdot$ Ex situ conservation $\cdot$ Genetic study $\cdot$ In situ conservation $\cdot$ Least water lily $\cdot$ Microsatellites

\section{Introduction}

Climate relicts are remnants of past populations that have become fragmented by climate-driven changes and habitat loss (Hampe and Jump 2011). These remnants were left behind during past range shifts and can persist today only in

Electronic supplementary material

Gregor Kozlowski

gregor.kozlowski@unifr.ch

Sébastien Bétrisey

sebastien.betrisey@unifr.ch

Nils Arrigo

nils.arrigo@unil.ch; nils.arrigo@gmail.com

Larissa Graf

graf.larissa@bluewin.ch

Julia Bilat

julia.bilat@unil.ch

Emanuel Gerber

emanuel.gerber@fr.ch enclaves with benign environmental conditions in areas with inhospitable regional climates (Woolbright et al. 2014). The Alps, along with the neighboring mountain ranges, played an important role in forming the biogeographical patterns in Europe and acted as a refugium for many taxa throughout several ice age cycles (Taberlet et al. 1998; Brochmann et al. 2003; Tribsch and Schönswetter 2003; Holderegger and Thiel-Egenter 2009; Windmaisser et al. 2016). During recent decades, the glacial and postglacial histories of

1 Natural History Museum Fribourg, Chemin du Musée 6, 1700 Fribourg, Switzerland

2 Department of Biology and Botanical Garden, University of Fribourg, Chemin du Musée 10, 1700 Fribourg, Switzerland

3 Department of Ecology and Evolution, Biophore Building, University of Lausanne, 1015 Lausanne, Switzerland

4 Kantonsschule Wattwil, Näppisuelistrasse 11, 9630 Wattwil, Switzerland 

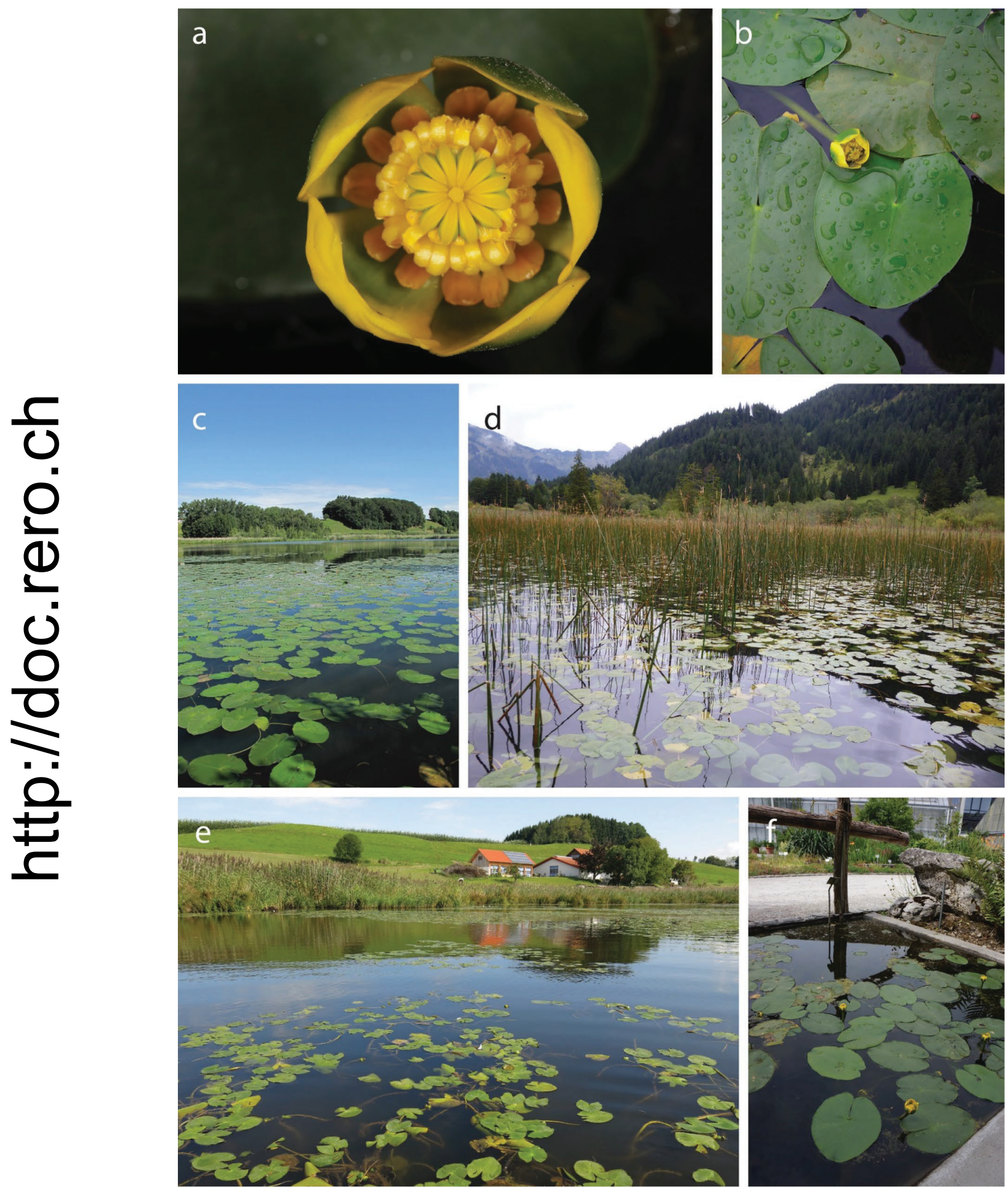
4Fig. 1 Nuphar pumila in the Alps and neighboring mountain ranges. a Flowers of $N$. pumila with deeply lobed stigmatic discs. b Floating leaves of $N$. pumila. c Fully introgressed population of $N$. pumila at the Lac de Lussy site (LUS, Switzerland); d the Haldensee site (HAL, Austria), which has one of the most preserved and pure populations of N. pumila in the Alps; and e the Schlossweiher site (SIG), which has up to 1000 individuals of $N$. pumila and is one of the bestpreserved natural populations of the species in southern Germany. $\mathbf{f}$ Ex situ culture of $N$. pumila from Lac des Joncs (Switzerland) in the Botanical Garden of the University of Fribourg (BGF)

arctic-alpine and boreal-alpine plant species have been extensively investigated (Stehlik et al. 2002; Stehlik 2003; Paun et al. 2008; Ronikier et al. 2012; Winkler et al. 2012; Eidesen et al. 2013). However, many relict taxa of the alpine region still await thorough analysis, since only a few punctual studies have explored the conservation status of the glacial relicts in Europe (Schmitt et al. 2010; Zimmermann et al. 2010). One of the reasons for this shortfall is the lack of a uniform definition of a glacial relict and, consequently, the lack of an exhaustive list of the threatened relicts in Europe and/or in the Alps (Zimmermann et al. 2010). First, systematic attempts to enumerate alpine high-mountain and high-latitude plants with disjunct distributions date to the beginning of the twentieth century (Kulczynski 1924; Schroeter 1926; Wangerin 1932) and were further developed by Thorn (1960) and Walter and Straka (1970). More recently, some detailed lists and conservation status assessments of glacial relicts were published (Reisch 2001; Welk 2001; Zimmermann et al. 2010); however, the majority of these lists are concentrated on restricted geographic areas (mainly Germany). The lack of synthesis of alpine relicts hinders the development of international and concerted conservation initiatives.

In our study, we investigated the least water lily [Nuphar pumila (тIMм.) DC, Nymphaeaceae] (Fig. 1), one of the most emblematic glacial relicts with a very scattered relictual distribution in the Alps and neighboring mountain systems (Heslop-Harrison 1955; Meusel et al. 1965; Roweck 1988). N. pumila is a specialist species that is restricted to mountain lakes with relatively shallow banks and acidic waters. The species forms floating leaf communities in a specialized habitat (Oberdorfer 1977) and has been the focus of several studies [e.g., Heslop-Harrison (1953, 1955), Roweck and Reinöhl (1986), Roweck (1988) and Kozlowski and Eggenberg (2005)]. In alpine countries, $N$. pumila is of special interest due to its rarity and relict status. In France (Vosges and Jura), it benefits from regional-level protection (Mikolajczak and Ferrez 2005). In Switzerland, the species is endangered (EN, Bornand et al. 2016) and is completely protected at the national level (Käsermann and Moser 1999). In Germany and Austria, N. pumila is listed as a category 1 species (threatened with extinction) (Metzing et al. 2018; Niklfeld
1999), and in France, it is listed as vulnerable (VU; https:// uicn.fr/liste-rouge-france/).

There are only two European species in the genus Nuphar: the least water lily and the yellow water lily $(N$. lutea L.) (Padgett 2007). They are closely related and form fertile hybrids known as $N$. $\times$ spenneriana (Padgett et al. 1999). Hybridization seems to be very common among the Nuphar species and has been well documented in North America (Padgett 1998; Padgett et al. 1998; 2002) and Japan (Shiga and Kadano 2007, 2008). In the Alps, hybridization with $N$. lutea has been described as one of the main threats to the natural populations of $N$. pumila (Arrigo et al. 2016). Surprisingly, hybridization seems to be very rare in Eastern Europe and Asia (Volkova et al. 2018).

The present paper aimed to address the following questions and topics: (1) What is the difference between the past and present distributions of N. pumila in the Alps and the neighboring mountain ranges (e.g., evaluation of the population losses by comparing the number of extant populations with the historically documented but currently extinct populations)? (2) What are the main threats to the extant populations of $N$. pumila in this region? (3) Which regions and lakes are the most threatened? (4) How many ex situ collections of $N$. pumila exist in Switzerland, and what is their quality? (5) Using molecular methods, we aimed to elucidate the origin of the ex situ collections and reintroductions of $N$. pumila in Switzerland and the level of their hybridization with $N$. lutea. (6) Based on our results, we proposed the best conservation strategy for the remaining relict and pure populations of $N$. pumila in the Alps and neighboring mountain ranges.

\section{Materials and methods}

\section{Present and past distribution}

We reconstructed the historical and recent distribution of $N$. pumila and the hybrid $N . \times$ spenneriana using peer-reviewed literature, field studies and surveys conducted by environmental engineering or botanical institutions. The global distribution of $N$. pumila has been elucidated from the two most comprehensive studies on $N$. pumila and on the whole genus Nuphar (Roweck 1988; Padgett 2007). The present and past distributions of $N$. pumila were determined for the Alps and neighboring mountain ranges using the precise list of locations from Roweck (1988), for France with data from field surveys performed throughout Jura and Vosges (Mikolajczak and Ferrez 2005; Muller 2006), for Germany with field sheets from the "Aktionsprogramm zur Sanierung Oberschwäbischer Seen" (https://www.seeprogramm.de), and for Switzerland with data compiled by Kozlowski and 
Eggenberg (2005) (see Table S1 for a complete list of past and recent locations).

\section{Field surveys and sampling for molecular analyses}

Our field surveys and sampling covered the entire species distribution in the Alps and neighboring mountain ranges. They included all existing populations from Switzerland and Austria as well as the selected populations from all mountain ranges where N. pumila occurs naturally in France (Jura and Vosges) and southern Germany (Black Forest, Eastern Baden-Württemberg and Bavaria). Additionally, all botanical gardens with ex situ collections and introduced populations in Switzerland were sampled. The field work was conducted and the collections were made in 2014 at the height of the growing season (June/August). At each study site, we precisely counted the number of floating leaves of $N$. pumila and $N . \times$ spenneriana and estimated the number of individuals based on the methodology described in Kozlowski and Eggenberg (2005). The human impact was assessed through direct observations in the field (especially signs of recreation and tourism, fishing and swimming activities, as well as boat traffic in the vicinity of the $N$. pumila communities) and discussion with the local administration and scientists. A comprehensive assessment of the macrophyte vegetation was conducted, especially for the floating-leaf species, to analyze the risks of the potential competitors among or in the direct vicinity of $N$. pumila (categorized as strong or extreme depending on the size of the $N$. pumila population and competitors) or in the surrounding areas (moderate). To estimate the risk of future hybridization, we also investigated the vegetation in each water body to locate $N$. lutea individuals. Information on the level of eutrophication of the investigated water bodies was taken from the published literature and available field surveys; quantitative data [phosphate $\left(\mathrm{PO}_{4}\right)$ concentration] were available for SIG, STO, $\mathrm{HAL}, \mathrm{ABB}$ and $\mathrm{SCH}$ through publicly available analyses mandated by the states (seenprogramm.de; ages.at; sierm. eaurmc.fr); for BAC, JON, LUS, GRA and KAM, we based the intensity of the threat on the qualitative data available in the literature (Kozlowski and Eggenberg 2005; Mikolajczak and Ferrez 2005); and for FIL, ROH and STI, the intensity of eutrophication was based on discussions with nature reserve managers (unpublished data).

For the molecular analyses, the leaves were washed thoroughly in water, dried with paper towels and stored in plastic bags with silica gel (Chase and Hills 1991). Altogether, six ex situ collections from botanical or private gardens and three introduced populations were sampled (Tables 1,2). The leaf material was retrieved from 6 to 14 individuals per collection/reintroduction for a total of 73 individuals (Table 2). Due to a small ex situ collection size, only three individuals were collected in Uster (UST), three in Wangen
(WAN), and four in the reintroduced population in Birchweiher (BIR). All voucher specimens (one individual per population) were deposited in the herbarium of the Natural History Museum in Fribourg, Switzerland (NHMF).

\section{Molecular analyses}

The DNA extraction methodology, wetlab procedures and statistical analysis of SSR genotypes were described in detail in companion paper published earlier (Arrigo et al. 2016). These data are available online as a unified SSR call-set (https://datadryad.org/resource/doi:10.5061/dryad $.8 \mathrm{f} 0 \mathrm{~d} 4$ ? show $=$ full) that we explore here further to outline the prevalence of hybrids in the sampling sites and establish the origin of the ex situ collections. The presence of the hybrid genotypes was assessed via the hybrid indexes computed with Hindex V 1.42 (Buerkle 2005). We followed the procedure described in detail in Arrigo et al. (2016), in which two sets of specimens representative of N. pumila and $N$. lutea are considered a priori. These groups allow the identification of alleles specific to each species and the computation of the hybrid index for any individual of putative hybrid origin. The obtained Hindex values range from 0 (for the pure N. pumila) to 1 (for the pure N. lutea specimens). The first generation (F1s) as well as advanced generation hybrids (F2s, F3s, F4s, etc.) get Hindex values near 0.5 , while advanced backcrosses diverge towards either parental pool, with Hindex values trending to 0 or 1 . We aimed to identify the non-pure genotypes and considered those individuals with Hindex values ranging between 0.1 and 0.9 to be of putative hybrid origin. This tool is suitable for the analysis of potentially clonally reproducing species as it does not require assumptions regarding Hardy-Weinberg equilibrium. Additionally, this approach accommodates mixtures of marker types, allowing the use of all the investigated SSR loci (that were treated as codominant, except for NLGA7, which was recoded as allelic presences/absences and declared dominant). The origins of the ex situ specimens were assessed by checking the SSR genotypes observed in the expected populations of origin (Arrigo et al. 2016). The specificity of this approach was possible because all the populations differed from each other by specific alleles and had a near-clonal diversity structure (when excluding hybrid genotypes). This feature allows the non-ambiguous identification of the population of origin of any sample.

\section{Results}

\section{Present and past distribution}

Nuphar pumila has a boreal distribution from Scandinavia to Siberia, Japan and Central China (Fig. 2a). Additionally, 
Table 1 Characterization of threats observed in all sampled and investigated study sites

\begin{tabular}{|c|c|c|c|c|c|c|c|c|c|}
\hline Site (code) & $\begin{array}{l}\text { Altitude (m } \\
\text { a.s.l) }\end{array}$ & NDD/EDD & $\begin{array}{l}\text { N. pumila } \\
\text { individuals }\end{array}$ & $\begin{array}{l}\text { Hybrid indi- } \\
\text { viduals }\end{array}$ & Hybridization & Eutroph & Comp & Human impact & $\begin{array}{l}\text { Presence } \\
\text { N. lutea }\end{array}$ \\
\hline \multicolumn{10}{|l|}{ Austria } \\
\hline $\begin{array}{l}\text { Haldensee } \\
\text { (HAL) }\end{array}$ & 1129 & $47.49 / 10.58$ & $1001-2500$ & 0 & - & - & - & + & No \\
\hline \multicolumn{10}{|l|}{ Germany } \\
\hline $\begin{array}{l}\text { Schlossweiher } \\
\text { (SIG) }\end{array}$ & 685 & $47.71 / 9.94$ & $501-1000$ & 0 & + & ++ & + & - & No \\
\hline $\begin{array}{l}\text { Stockweiher } \\
\text { (STO) }\end{array}$ & 680 & $47.82 / 9.83$ & $1001-2500$ & 0 & + & +++ & - & + & No \\
\hline $\begin{array}{l}\text { Filzweiher } \\
\text { (FIL) }\end{array}$ & 714 & $47.91 / 11.23$ & 0 & $101-250$ & +++ & - & + & - & Yes \\
\hline $\begin{array}{l}\text { Röhrenmoos } \\
\text { (ROH) }\end{array}$ & 843 & $47.69 / 10.49$ & $101-250$ & $101-250$ & +++ & ++ & - & - & Yes \\
\hline $\begin{array}{l}\text { Sticherweiher } \\
\text { (STI) }\end{array}$ & 880 & $47.65 / 10.48$ & $0-10$ & 0 & ++ & ++ & +++ & +++ & Yes \\
\hline $\begin{array}{l}\text { Schlüchtsee } \\
(\mathrm{SCH})\end{array}$ & 935 & $47.79 / 8.26$ & 0 & $1001-2500$ & +++ & ++ & + & ++ & Yes \\
\hline \multicolumn{10}{|l|}{ France } \\
\hline $\begin{array}{l}\text { Lac de } \\
\text { l'Abbaye } \\
\text { (ABB) }\end{array}$ & 875 & $46.54 / 5.92$ & $0-10$ & $0-10$ & +++ & ++ & +++ & + & Yes \\
\hline $\begin{array}{l}\text { Etang } \\
\text { Bachetey } \\
\text { (BAC) }\end{array}$ & 793 & $47.94 / 6.61$ & $1001-2500$ & 0 & - & - & - & - & No \\
\hline \multicolumn{10}{|l|}{ Switzerland } \\
\hline $\begin{array}{l}\text { Lac des Joncs } \\
\text { (JON) }\end{array}$ & 1235 & $46.51 / 6.95$ & $0-10$ & 0 & - & ++ & +++ & +++ & No \\
\hline $\begin{array}{l}\text { Lac de Lussy } \\
\text { (LUS) }\end{array}$ & 823 & $46.54 / 6.90$ & 0 & $>10,000$ & +++ & ++ & - & - & Yes \\
\hline $\begin{array}{l}\text { Gräppelensee } \\
\text { (GRA) }\end{array}$ & 1282 & $47.21 / 9.29$ & $>10,000$ & 0 & - & - & - & - & No \\
\hline $\begin{array}{l}\text { Kämmosteich } \\
\text { (KAM) }\end{array}$ & 511 & $47.26 / 8.83$ & $1001-2500$ & $1001-2500$ & +++ & ++ & + & - & Yes \\
\hline $\begin{array}{l}\text { Erliweiher } \\
\text { (ERL) }\end{array}$ & 780 & $47.30 / 8.93$ & $101-250$ & 0 & + & ++ & +++ & - & No \\
\hline $\begin{array}{l}\text { Birchweiher } \\
\text { (BIR) }\end{array}$ & 549 & $47.35 / 8.79$ & $51-100$ & 0 & + & ++ & +++ & - & No \\
\hline Rathvel (RAT) & 1225 & $46.54 / 6.98$ & $51-100$ & 0 & - & ++ & +++ & - & No \\
\hline
\end{tabular}

Severity of threats: - low, + moderate, ++ strong, +++ extreme. All sites are natural populations, except for ERL, BIR, and RAT, which are introductions

scattered and disjointed European populations exist in Spain (Asturias), England, France, Switzerland, Germany, Austria, the Czech Republic, and possibly in Croatia and Romania. The study sites (Fig. 2b) reflected the present distribution of the species in the Alps and adjacent mountain ranges (Fig. 2c). In total, 104 historical populations have been listed in the literature: 37 populations of $N$. pumila (some of them with possible hybrid individuals) still exist in the studied area; while, 67 populations are considered extinct, of which 9 populations were reported in the literature to be composed entirely of hybrid individuals (based on both morphology and genetic analysis for two of them [(Lac de Lussy and
Schlüchtsee)]). Most of the extant populations (31 out of 37; $84 \%$ ) occur in the Vosges mountains (France) and in southeastern Germany. Only one population exists in Austria, while three populations exist in Switzerland and two populations exist in the French Jura (Fig. 2c). Altogether, 64\% of all known historic populations of $N$. pumila in the investigated area are extinct today. The most affected regions were the Black Forest (Germany), which had a population loss of $100 \%$ (6 populations out of 6); Jura Mountains (France), which had a population loss of $88 \%$ (14 populations out of 16); and Switzerland, which had a population loss of $82 \%$ (14 populations out of 17). In the Black Forest, only hybrid 


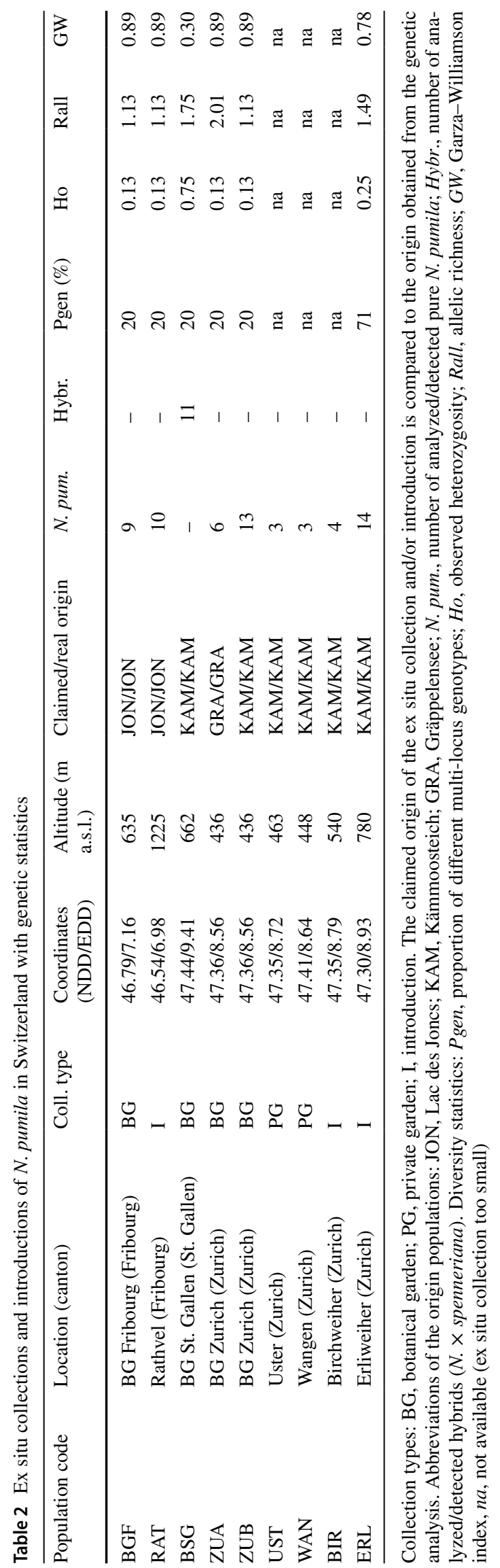

populations still exist. South-central Germany lost 58\% (19 out of 33) of the populations, and the Vosges mountains lost $45 \%$ (14 out of 31 ) of the populations.

\section{Threats}

The most frequent threat detected in the investigated natural populations (without introductions: ERL, BIR, and RAT) was eutrophication, which strongly or extremely affected $69 \%$ of the sites, followed by hybridization (54\%), competition and human impacts (both 23\%) (Table 1). The most severe pressure, however, came from hybridization, which was considered extreme in six of the studied water body sites ( $46 \%$ of natural populations), followed by that of competition, which was considered extreme in three study sites (23\%). Eutrophication was strong in almost all studied sites, but only one site was considered hypertrophic (STO) due to the past addition of phosphates for fishing activities. The human impacts were generally not very severe, as different protection measures have been undertaken for the conservation of this species and more generally for ponds and lakes during recent decades. However, for two very small populations (STI and JON), the human impacts were still putting the survival of the species at risk. We did not detect any very-high-intensity threats for only four populations (GRA, BAC, SIG, and HAL) (Fig. 1d, e). Furthermore, three populations were extremely small, possessing no more than ten individuals (STI, ABB, and JON), and could completely disappear due to any stochastic event (Table 1).

The populations facing the fewest threats were located at high altitudes (greater than $1000 \mathrm{~m}$ a.s.l. (HAL and GRA)), where $N$. lutea was still absent, or in the Vosges mountains (BAC), where the populations of $N$. pumila did not seem to have been impacted by hybridization (Mikolajczak and Ferrez 2005).

\section{Ex situ conservation of N. pumila in Switzerland}

No more than three botanical gardens and two private gardens currently grow $N$. pumila in ex situ cultures. Two botanical gardens (Geneva and Lausanne) cultivated the species in the past but lost their ex situ collections during recent decades. Table 2 lists all known ex situ cultures and introductions of $N$. pumila in Switzerland. Two private gardens (UST, WAN) have been added to our study since they were officially assigned conservation purposes by the cantonal administration, along with three successful introductions of the species in Switzerland (one in the canton of Fribourg and two in the canton of Zurich). Three extant populations in Switzerland (out of four) were held in ex situ cultures. The population from Kämmoosteich (KAM) encompassed two botanical gardens (BSG and ZUB), two private gardens (UST and WAN) and two reintroductions (BIR and ERL). 
Fig. 2 Recent and historical distributions of N. pumila and the investigated populations: a the global distribution of $N$. pumila, modified from Roweck (1988) and Padgett (2007); b the investigated populations in the Alps and neighboring mountain ranges; and $\mathbf{c}$ the historical and present populations of $N$. pumila and its hybrids ( $N$ $\times$ spenneriana). Black circles: pure populations of $N$. pumila. White circles: hybrid populations of $N \times$ spenneriana. White circles with a black dot: $N$. pumila and $N \times$ spenneriana coexisting. Black squares: introductions. Background maps: https://d-maps.com/

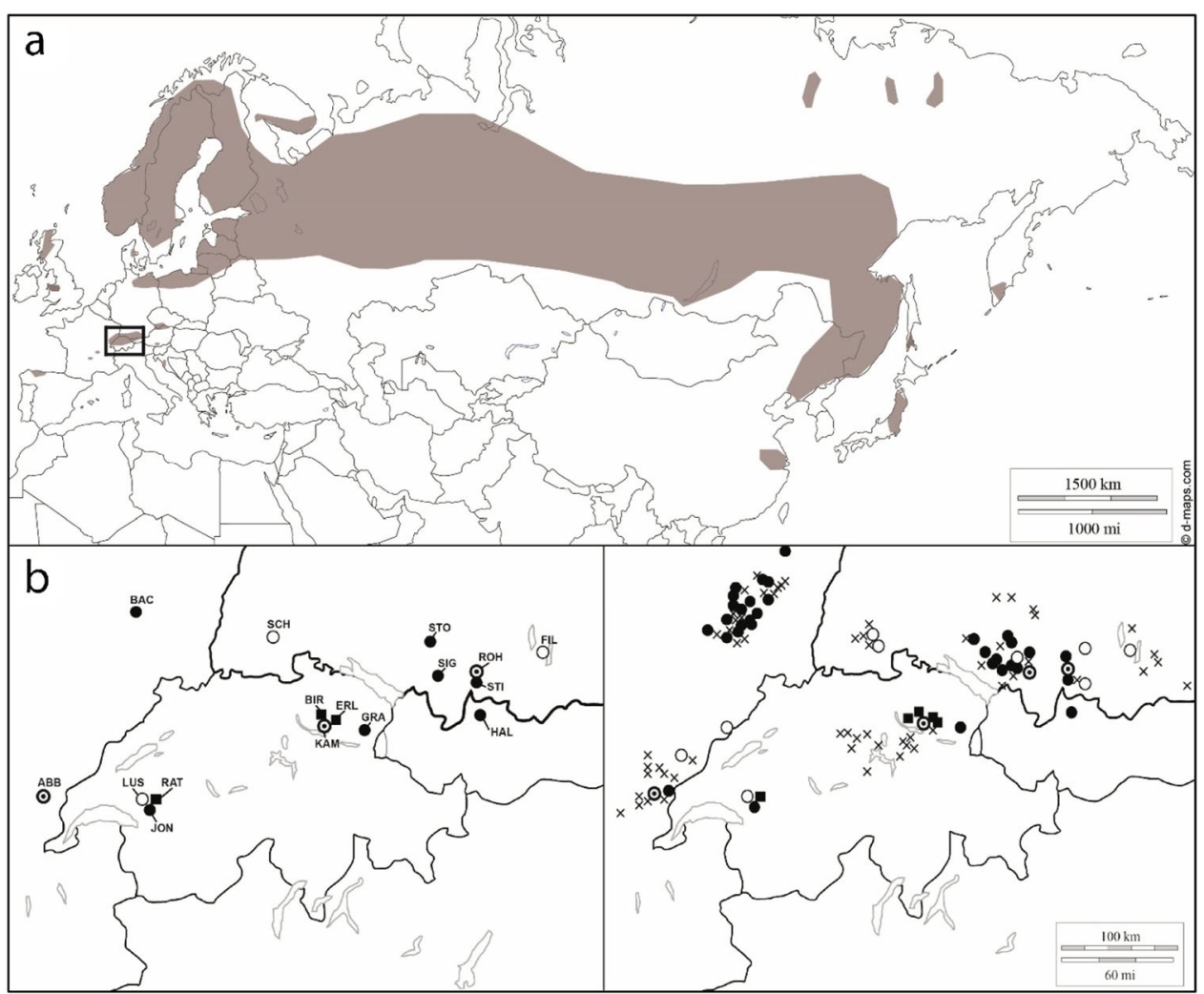

The population from Lac des Joncs (JON) comprised one botanical garden (BGF; Fig. 1f) and one introduction (RAT). The population from Gräppelensee was only located in one botanical garden (ZUA). The population from Lac de Lussy was not kept in any living ex situ culture (Table 2; Fig. 1c). The genetic provenance of the ex situ cultures in Switzerland matches their supposed origin. Furthermore, all ex situ cultures and introductions belonged to the pure N. pumila genotype, except for one culture in Botanical Garden St. Gallen (BSG), which contained only hybrid individuals. This culture should be replaced as soon as possible. This could be explained by an error during the initial collection of the specimens or by an accidental hybridization in the botanical garden.

\section{Discussion}

\section{Current conservation status of $N$. pumila in the Alps and neighboring mountain ranges}

Our results clearly show that the present situation of the N. pumila populations in the Alps is alarming. Since the beginning of the twentieth century, important losses in these populations have worsened the situation of the species in nearly its entire range in the studied area from France to Austria. Eutrophication and human impacts have caused losses in many locations, and the hybridization process has already erased genetically pure populations from the Black Forest in Germany.

Although hybridization is a natural process and could even play an important role in the diversification of species, it has been shown that the introgression process between $N$. pumila and N. lutea leads to the elimination of pure $N$. pumila in the long term (Arrigo et al. 2016). Therefore, it is imperative that conservation efforts both in situ and ex situ focus on the protection of the remaining genetically pure populations. In the case of pure individuals that still remain in hybrid populations, we propose preserving those individuals in ex situ collections to keep the pure genotype in the long term. Thus, reintroduction in closed ponds or after the complete disappearance of the original population could still be possible in the future. Concerning the entirely hybrid populations, the importance of conservation must be considered on a case-by-case basis. While ex situ conservation of hybrid individuals is not recommended and could even represent a risk of propagation, in situ conservation of a hybrid population should be considered the only way to avoid the complete loss of the hybridized species and should therefore be implemented (Allendorf et al. 2001). The active protection of hybrid populations was already proposed in the United Kingdom (Heslop-Harrison 1955) and is already in action through the Black Forest (e.g., Schlüchtsee, Germany). 
At the global scale, N. pumila is considered a species of least concern (LC) by the IUCN Red List of Threatened Species (Maiz-Tome 2016). However, this assessment incorporated the North American N. advena and did not follow the division of the genus proposed by Padgett (2007) in his monograph. This was surprising since the separation between the old-world water lilies (sect. Nuphar) and the new world members of the genus (sect. Astylus) is strongly supported by morphological and molecular data (Padgett et al. 1999). This rare relict species is indeed endangered in several countries around the Alps. Thus, a new global conservation status assessment of $N$. pumila was highly desirable.

\section{Conservation of N. pumila in Switzerland}

The conservation of $N$. pumila across Switzerland has advanced well, both in situ through the monitoring of the populations and high protection levels of the water bodies with the species and ex situ through living collections and introduction trials. It is well accepted that in situ conservation should be generally prioritized; however, in situ conservation is particularly challenging in the face of direct hybridization threats (LUS, KAM) or high levels of eutrophication (JON, LUS, KAM). Even the current human impacts could be damaging when occurring in populations with very few individuals (JON). Previous genetic analyses (Arrigo et al. 2016) showed that populations were composed of clonal individuals. It is, therefore, possible to protect the entire genetic diversity of a population through a single individual taken from a water body and cultivated in a botanical garden. The main difficulties consist of avoiding hybridization and keeping the culture alive for a long time period. To limit the eventuality of accidental pollination in an ex situ culture, it is strongly recommended that all other plants belonging to the genus Nuphar be eliminated from the surroundings of the ex situ cultures and that the fruits be prevented from releasing seeds. Since the materials held in botanical gardens could be used for reintroduction programs, it is very important to know the origins of the ex situ cultures.

In Switzerland, living ex situ collections play an important role as a backup of the last three pure N. pumila populations in the country and can be used for introduction programs. Ex situ conservation of pure individuals is particularly important for the Kämmosteich (KAM) population, which is composed of pure and hybrid groups. The fourth extant Swiss population from Lac de Lussy was composed only of hybrid individuals and thus does not need to be kept in any living ex situ culture. More generally, special priority should be given to preserving pure populations at locations higher than $1000 \mathrm{~m}$ a.s.l., where the chance of hybridization is still very low. This has been done in the canton of Fribourg with the Rathvel population (RAT), which is an introduction of the population from Lac des Joncs, which has been declining for years (Kozlowski 2001). However, this strategy could be compromised in the future by the shift of the closely related $N$. lutea towards higher altitudes due to global climate change. Another strategy could be seed collection, especially for long-term conservation.

\section{Conservation strategies across the Alps and neighboring mountain ranges}

The in situ conservation of pure $N$. pumila should be prioritized for the last remaining populations across the Alps. This is especially the case for populations that are still in good condition, such as the populations in the Vosges mountains and some populations at high altitudes, e.g., the Gräppelensee population in Switzerland and the only known $N$. pumila population in western Austria (Haldensee in Tirol, Fig. 1d). For those populations, in situ measures, such as the strict limitation of human activities, frequent monitoring of the population and competitive species, avoidance of eutrophication or any water quality alterations, and prevention of cultivation of other Nuphar species by local individuals in adjacent private ponds (particularly important in HAL, a very touristic spot), should be undertaken to protect the species in the long term.

In nearly all other investigated populations, hybridization, damage to the natural environment and poor population dynamics were strongly pronounced, and the survival of pure $N$. pumila cannot be guaranteed in the next few decades by protecting the species only in situ. Based on the genetic specificity of the species (Arrigo et al. 2016), especially the clonality of the populations, we considered that conservation through living ex situ culturing should be prioritized for the nearly extinct populations or populations with ongoing hybridization processes. This is the case for the last two remaining populations in the Jura Mountains (Bellefontaine and Lac de l'Abbaye). Removing several pieces of the rhizomes for ex situ proliferation probably represents the last possibility to save the genotype and population of Bellefontaine, which was already nearly extinct in 2005 (Mikolajczak and Ferrez 2005). For the Lac de l'Abbaye population, the situation is also alarming, with fewer than ten remaining individuals, which are completely surrounded by vigorous individuals of Nymphaea alba. Moreover, the hybridization process has been detected in one individual, making the future of this small population even more precarious. Ex situ conservation and introduction in highly suitable habitats seems to be the only way to preserve the last two pure populations of $N$. pumila in the Jura Mountains. However, it would be necessary to perform further genetic analyses to collect and preserve only the pure individuals.

Finally, concerning the population in southern Germany, we propose maintaining the conservation measures already taken in the Black Forest to protect the hybrid populations. 
For the populations in Bavaria and Baden-Württenberg, which represent the highest concentrations of $N$. pumila in the whole alpine area, it is important to prioritize conservation needs. We propose the strengthening of the in situ conservation measures (e.g., avoiding human impact and chemical alteration of the water) for pure populations in a good conservation condition (SIG or even STO if the eutrophication is drastically limited) as well as the preservation of the pure genotype for very small populations (e.g., STI) and populations coexisting with hybrids (e.g., ROH) by ex situ conservation of pure individuals. Finally, additional field surveys and analyses should still be conducted at a regional scale for the rest of the known populations of south Germany.

\section{Wetland glacial relicts of the Alps}

Nuphar pumila belongs to boreal-alpine glacial relicts (Aeschimann et al. 2004; Varga and Schmitt 2008), which survive in the Alps and neighboring regions, mainly in wetland communities (Reisch 2001; Welk 2001). A dozen of such boreal glacial relicts are growing in ecologically similar habitat types (mires, fens, and peatbogs) and thus often occur in the same protected areas as N. pumila (Kozlowski and Eggenberg 2005). The dramatic decline and conservation situation of $N$. pumila is, therefore, not an exception among its counterparts, since all these boreal and wetland glacial relicts are threatened in the Alps. This is especially the case for Saxifraga hirculus, Juncus stygius, Eriophorum gracile, Carex heleonastes, $C$. chordorrhiza and Betula humilis, which are endangered, critically endangered, or even extinct in several alpine countries (e.g., S. hirculus in Germany and Austria) (Metzing et al. 2018; Niklfeld 1999). Betula nana, Carex dioca, C. limosa, Lycopodiella inundata and Scheuchzeria palustris, although still possessing some viable populations in several alpine countries, also doubtless belong to the group of highly threatened plants. Only the situations of Trichophorum alpinum, Vaccinium oxycoccos and V. uliginosum seem to be less alarming in the Alps (Bornand et al. 2016; Metzing et al. 2018; Niklfeld 1999; https://uicn.fr/liste-rouge-france/).

Similarly, the threat of hybridization is not exclusive to $N$. pumila. A similar level of threat has been observed in the genus Betula, with $B$. nana hybridizing with B. pubescens (Anamthawat-Jonsson and Thorsson 2003) and B. humilis hybridizing with B. pendula and B. pubescens (Natho 1959; Jadwiszczak et al. 2011, 2012). Moreover, natural hybridization between the various species of Carex seems to be quite frequent. Hybrids of $C$. chordorrhiza (with $C$. canescens), $C$. dioica (with C. stellulata), C. heleonastes (with C. canescens, C. tenuiflora), and C. limosa (with C. magellanica, C. paleacea, $C$. rariflora, and $C$. livida) have been detected in many regions of the Northern Hemisphere (Cayouette and Cattling 1992).

The threatened alpine occurrences of $N$. pumila, along with other wetland glacial relicts, are typical rear edge populations (sensu Hampe and Petit 2005). They are all particularly affected by the combination of global warming and habitat degradation (Hampe and Jump 2011). Their value as long-term stores of genetic diversity and speciation is inestimable. Such isolated edge populations are often disproportionally important for the survival and evolution of a given taxon (Hampe and Petit 2005). Thus, an international integration of research and conservation programs is needed to limit the decline of such threatened species in the Alps.

Acknowledgements We are grateful to the following persons and institutions for their precious help, collaboration and/or issue of permissions: Switzerland-Botanical Gardens of St-Gall, Zürich, Geneva, Lausanne and Fribourg; Benoît Clément, Botanical Garden of the University of Fribourg; Marius Achermann and Francesca Cheda, Service de la Nature et du paysage de l'Etat de Fribourg; Dr. Andreas Keel, Amt für Landschaft- und Naturschutz, Kanton Zürich; Claudia Huber, UNA, Bern; Rolf Heeb and Christian Peisker, Kantonsschule Wattwil; Luca Champoud and Valentine Kam, Collège du Sud, La Frasse; François Genoud, Auberge du Lac des Joncs, Les Paccots; Coordination régionale pour la protection de la flore (FR-GE-NE-VD); Dr. Stephan Eggenberg, Info Flora. France-Eric Brugel and Julien Guyonneau, Conservatoire botanique national de Franche-Comté; Sophie Daucourt, Direction Régionale de l'Environnement, de l'Aménagement et du Logement de Franche-Comté (DREAL); Alain David, Office National de l'Eau et des Milieux Aquatiques (ONEMA); Alain Piot, Hôtel et lac de l'Abbaye, Grande-Rivière; owners of the pond Bachetey, Haute-Saône. Austria-Michaela Messner, Bezirkshauptmannschaft Reutte; municipalities of Grän and Nesselwängle, Tirol. GermanyGünter Riegel, Regierungsbezirk Schwaben; Dr. Klaus Neugebauer, Regierungsbezirk Oberbayern; Hans Lampartner, Regierungspräsidium Tübingen; Bertrand Schmidt, Landratsamt Ravensburg; Dr. Ulrich Weiland, Zweckverband Allgäuer Moorallianz; Dr. Stephanie Socher, Bayerischen Landesamt für Umwelt in Augsburg; Naturpark Südschwarzwald; Sigrid Rossiwal, Regierung von Oberbayern, Uwe Grabner, Starnberg; Josef Kunsler, Bad Endorf; NSG Eggstätt-Hemhofer Seenplatte; Bernadette Zimmermann, Regierungspräsidium Freiburg. We thank the Natural History Museum Fribourg (Switzerland) and the Fonds de recherche of the University of Fribourg (Switzerland, Project number 516) for their logistic and financial support. Nils Arrigo was funded by an SNSF Ambizione research Grant (PZ00P3_148224).

Author contributions GK and SB developed the research ideas; SB, LG, and EG collected the data and samples; NA and JB carried out molecular analyses; SB, NA, and GK analyzed the data and led the writing of the manuscript.

\section{Compliance with ethical standards}

Conflict of interest The authors declare that they have no conflict of interest in relation with this article. 


\section{References}

Aeschimann D, Luber K, Moser DM, Theurillat J-P (2004) Flora alpina, vol 1-3. Haupt Verlag, Bern

Allendorf F, Leary R, Spruell P, Wenburg J (2001) The problems with hybrids: setting conservation guidelines. Trend Ecol Evol 16:613-622

Anamthawat-Jonsson K, Thorsson AT (2003) Natural hybridisation in birch: triploid hybrids between Betula nana and B. pubescens. Plant Cell Tissue Org Cult 75:99-107

Arrigo N, Bétrisey S, Graf L, Bilat J, Gerber E, Kozlowski G (2016) Hybridization as a threat in climate relict Nuphar pumila (Nymphaeaceae). Biodivers Conserv 25:1863-1877

Bornand C, Gygax A, Juillerat P, Jutzi M, Möhl A, Rometsch S, Sager L, Santiago H, Eggenberg S (2016) Rote Liste Gefässpflanzen. Gefährdete Arten der Schweiz. Bundesamt für Umwelt, Bern und Info Flora, Genf. Umwelt-Vollzug Nr. 1621

Brochmann C, Gabrielsen TM, Nordal I, Landvik JY, Elven R (2003) Glacial survival or tabula rasa? The history of North Atlantic biota revisited. Taxon 52:417-450

Buerkle CA (2005) Maximum-likelihood estimation of a hybrid index based on molecular markers. Mol Ecol Notes 5:684-687

Cayouette J, Cattling PM (1992) Hybridization in the genus Carex with special reference to North America. Bot Rev 58:351-440

Chase WM, Hills HG (1991) Silica gel: an ideal material for field preservation of leaf samples for DNA studies. Taxon 40:215-220

Eidesen PB, Ehrich D, Bakkestuen V, Alsos IG, Gilg O, Taberlet P, Brochmann C (2013) Genetic roadmap of the Arctic: plant dispersal highways, traffic barriers and capitals of diversity. New Phytol 200:898-910

Hampe A, Petit RJ (2005) Conserving biodiversity under climate change: the rear edge matters. Ecol Lett 8:461-467

Hampe A, Jump AS (2011) Climate relicts: past, present, future. Annu Rev Ecol Evol 42:313-333

Heslop-Harrison Y (1953) Nuphar intermedia Lebed., a presumed relict hybrid in Britain. Watsonia 3:7-25

Heslop-Harrison Y (1955) Nuphar Sm. J Ecol 43:342-364

Holderegger R, Thiel-Egenter C (2009) A discussion of different types of glacial refugia used in mountain biogeography and phylogeography. J Biogeogr 36:476-480

Jadwiszczak KA, Jablonska E, Klosowski S, Banaszek A (2011) Aneuploids in the shrub birch Betula humilis populations in Poland. Acta Soc Bot Pol 80:233-235

Jadwiszczak KA, Drzymulska D, Banaszek A, Jadwiszczak P (2012) Population history, genetic variation and conservation status of the endangered birch species Betula nana L. in Poland. Silva Fenn 46:465-477

Käsermann CH, Moser DM (1999) Merkblätter Artenschutz, Blütenpflanzen und Farne. Bundesamt für Umwelt, Wald und Landschaft (BUWAL), Bern, Switzerland

Kozlowski G (2001) Une plante rarissime dans le canton de Fribourg: le Nénuphar nain [N. pumila (Timm.) DC.]. Bull Soc Frib Sc Nat 90:60-71

Kozlowski G, Eggenberg S (2005) Vorkommen der Kleinen Teichrose Nuphar pumila und des Hybrids $N . \times$ intermedia in der Schweiz. Bot Helv 115:125-136

Kulczynski S (1924) Das boreale und arktisch-alpine Element in der mitteleuropäischen Flora. Bull de l'Ac Pol d Sc Série B 3:127-214

Maiz-Tome L (2016) Nuphar pumila. The IUCN red list of threatened species 2016: e.T167888A1179645

Metzing D, Garve E, Matzke-Hajek G (2018) Rote Liste und Gesamtartenliste der Farn- und Blütenpflanzen (Trachaeophyta) Deutschlands. Bundesamt für Naturschutz. Naturschutz und Biologische Vielfalt 70:13-358
Meusel H, Mühlberg H, Fuchs HP (1965) Nymphaeaceae. In: Hegi G (ed) Illustrierte Flora von Mitteleuropa. Band III. Teil 3. Carl Hanser, München

Mikolajczak A, Ferrez Y (2005) Connaissance de la flore rare ou menacée de Franche-Comté, Nuphar pumila (Timm) DC., Conservatoire Botanique de Franche-Comté

Muller S (2006) Les plantes protégées de Lorraine. Distribution, écologie, conservation. Biotope, Mèze (collection Parthénope)

Natho G (1959) Variationsbreite und Bastardbildung bei mitteleuropäischen Birkensippen. Feddes Repert 61:211-273

Niklfeld H (1999) Rote Liste gefährdeter Pflanzen Österreichs. Grüne Reihe des Bundesministeriums für Umwelt Jugend und Familie. Band 10. Graz, Austria

Oberdorfer E (1977) Süddeutsche Pflanzengesellschaften Teil I. Zweite Auflage. Gustav Fischer, Stuttgart

Padgett DJ (1998) Phenetic distinction between the dwarf yellow waterlilies: Nuphar microphylla and N. pumila (Nymphaeaceae). Can J Bot 76:1755-1762

Padgett DJ (2007) A monograph of Nuphar (Nympheaceae). Rhodora 109:1-95

Padgett DJ, Les DH, Crow GE (1998) Evidence for the hybrid origin of Nuphar $\times$ rubrodisca (Nymphaeaceae). Am J Bot 85:1468-1476

Padgett DJ, Les DH, Crow GE (1999) Phylogenetic relationships in Nuphar (Nymphaeaceae): evidence from morphology, chloroplast DNA, and nuclear ribosomal DNA. Am J Bot 86:1316-1324

Padgett DJ, Shimoda M, Horky LA, Les DH (2002) Natural hybridization and the imperiled Nuphar of Western Japan. Aquat Bot $72: 161-174$

Paun O, Schönswetter P, Winkler M, Consortium I, Tribsch A (2008) Historical divergence vs. contemporary gene flow: evolutionary history of the calcicole Ranunculus alpestris group (Ranunculaceae) in the European Alps and the Carpathians. Mol Ecol $17: 4263-4275$

Reisch C (2001) Climatic oscillations and the fragmentation of plant populations-genetic diversity within and among populations of the glacial relict plants Saxifraga paniculata (Saxifragaceae) and Sesleria albicans (Poaceae). Dissertation zur Erlangung des Doktorgrades der Naturwissenschaften der Naturwissenschaftlichen Fakultät III, Biologie und Vorklinische Medizin der Universität Regensburg

Ronikier M, Schneeweis GM, Schönswetter P (2012) The extreme disjunction between Beringia and Europe in Ranunculus glacialis sl. (Ranunculaceae) does not coincide with the deepest genetic split-a story of the importance of temperate mountain ranges in arctic-alpine phylogeography. Mol Ecol 21:5561-5578

Roweck H (1988) Ökologische Untersuchungen an Teichrosen. Archiv für Hydrobiologie. Schweizerbart'sche Verlagsbuchhandlung, Supplementband. $81 \mathrm{Heft} 2 / 3$. Nägele u. Obermiller. Stuttgart, Germany

Roweck H, Reinöhl H (1986) Zur Verbreitung und systematischen Abgrenzung der Teichrosen Nuphar pumila und $N . \times$ intermedia in Baden-Württemberg. Veröffentlichungen Landesstelle Naturschutz Baden-Württemberg 61:81-151

Schmitt T, Muster C, Schönswetter P (2010) Are disjunct alpine and arctic-alpine animal and plant species in the western Palearctic really "relics of the cold past"? In: Habel JC, Assman T (eds) Relict species: phylogeny and conservation biology. Springer, Berlin, pp 239-252

Schroeter C (1926) das Pflanzenleben der Alpen. Eine Schilderung der Hochgebirgsflora. Verlag Albert Raustein, Zürich

Shiga T, Kadono Y (2007) Natural hybridization of the two Nuphar species in northern Japan: homoploid hybrid speciation in progress? Aquat Bot 86:123-131

Shiga T, Kadono Y (2008) Genetic relationships of Nuphar in central to western Japan as revealed by allozyme analysis. Aquat Bot $88: 105-112$ 
Stehlik I (2003) Resistance or emigration? Response of alpine plants to the ice ages. Taxon 52:499-510

Stehlik I, Blattner FR, Holderegger R, Bachmann K (2002) Nunatak survival of the high Alpine plant Eritrichium nanum (L.) Gaudin in the central Alps during the ice ages. Mol Ecol 11:2027-2036

Taberlet P, Fumagalli L, Wust-Saucy A-G, Cosson J-F (1998) Comparative phylogeography and postglacial colonization routes in Europe. Mol Ecol 7:453-464

Thorn K (1960) Bemerkungen zu einer Übersichtskarte vermutlicher Glazialreliktpflanzen Deutschlands. Mitteilungen der FloristischSoziologischen Arbeitsgemeinschaft 8:81-85

Tribsch A, Schönswetter P (2003) Patterns of endemism and comparative phylogeography confirm palaeoenvironmental evidence for Pleistocene refugia in the eastern Alps. Taxon 52:477-497

Varga ZS, Schmitt T (2008) Types of oreal and oreotundral disjunctions in the western Palearctic. Biol J Linn Soc 93:415-430

Volkova PA, Arutyunyan NG, Schanzer IA, Chemeris EV, Bobrov AA (2018) Genetic variability of Eurasian Nuphar species unravels possible routes in which freshwater plants could fill their wide areas. Aquat Bot 145:49-57

Walter H, Straka H (1970) Arealkunde. Floristisch-historische Geobotanik. Verlag Eugen Ulmer, Stuttgart

Wangerin W (1932) Florenelemente und Arealtypen. Beih Bot Zentralbl 49:515-566

Welk E (2001) Arealkundliche Analyse und Bewertung der Schutzrelevanz seltener und gefährdeter Gefässpflanzen Deutschlands.
Dissertation zur Erlangung des Doktorgrades vorgelegt an der Mathematisch-Naturwissenschaftlich-Technischen Fakultät der Martin-Luther-Universität Halle-Wittenberg

Windmaisser T, Kattari S, Heubl G, Reisch C (2016) Glacial refugia and postglacial expansion of the alpine-prealpine plant species Polygala chamaebuxus. Ecol Evol 6:7809-7819

Winkler M, Tribsch A, Schneeweis GM, Brodbeck S, Gugerli F, Holderegger R, Abbott RJ, Schönswetter P (2012) Tales of the unexpected: phylogeography of the arctic-alpine model plant Saxifraga oppositifolia (Saxifragaceae) revisited. Mol Ecol 21:4618-4630

Woolbright SA, Whitham TG, Gering CA, Allan GJ, Bailey JK (2014) Climate relicts and their associated communities as natural ecology and evolution laboratories. Trends Ecol Evol 29:406-416

Zimmermann M, Vischer-Leopold M, Ellwanger G, Ssymak A, Schröder E (2010) The EU habitat directive and the German Natura 200 network of protected areas as tool for implementing the conservation of relict species. In: Habel JC, Assman T (eds) Relict species: phylogeny and conservation biology. Springer, Berlin, pp 323-340 